\title{
Actualization of Religious Values through Religious Tourism on the River As a Source of Social Studies Learning
}

\author{
Ersis Warmansyah Abbas ${ }^{1}$, Jumriani ${ }^{2}$, Muhammad Rezky Noor Handy 3, \\ Syaharuddin 4, Nadiatul Izmi 5
}

DOI : 10.35445/alishlah.v13i3.1013

\begin{tabular}{ll}
\hline Article Info & Abstract \\
\hline Keywords: & Quality human resources are needed to support development. To produce these \\
Religious Values; & resources requires a variety of attitudes. One of them is religious attitudes as a \\
Religious Tourism; & preventive measure against immoral behaviour currently rife in society. From a \\
Social Sciences & local perspective, religious tourism can be done to learn in realizing religious \\
& attitudes. In the city of Baniarmasin, there is a religious tour of the Habib Basirih \\
& Dome that can actualize students' religious values through various religious \\
& activities. This article explores religious tourism on the river as a learning \\
& resource to actualize students' religious values. Qualitative approach with a \\
& descriptive method is used with data collection techniques through interviews, \\
& observation, and documentation. The validity of the data is done through \\
triangulation of sources, time, and techniques. The study results ensure that & religious tourism on the river, precisely in the Habib Basirih Dome, can be used \\
to actualize students' religious attitudes. Therefore, teachers can use it by & planning, implementing, and evaluating in the context of social studies subjects \\
by the content of religious characters through religious tourism on the river, & \\
precisely in the Basirih Dome.
\end{tabular}

Kata kunci:

Nilai Religius;

Wisata Religi;

Ilmu Pengetahuan Sosial

\begin{abstract}
Abstrak
Sumber daya manusia yang berkualitas sangat diperlukan untuk menunjang pembangunan. Untuk menghasilkan sumber daya tersebut diperlukan berbagai sikap. Satu diantaranya adalah sikap religius sebagai upaya preventif terhadap perilaku amoral yang sekarang ini marak terjadi di masyarakat. Dalam perspektif lokal, wisata religi dapat dilakukan untuk kepentingan pembelajaran dalam mewujudkan sikap religius. Di Kota Banjarmasin, terdapat wisata religi Kubah Habib Basirih yang dapat dimanfaatkan untuk mengaktualisasikan nilai religius peserta didik melalui berbagai aktivitas keagamaan di dalamnya. Artikel ini bertujuan untuk mengeksplorasi wisata religi di bantaran sungai sebagai sumber belajar untuk mengaktualisasikan nilai religius peserta didik. Pendekatan kualitatif dengan metode deskriptif digunakan dengan teknik pengumpulan data melalui wawancara, observasi, dan dokumentasi. Validitas
\end{abstract}

\footnotetext{
${ }^{1}$ Un iv ersitas Lambung Mangkurat, Ba njarmasin, In donesia

Em ail: ersiswa@ulm.ac.id

2 Un iv ersitas Lambung Mangkurat, Ba njarmasin, In donesia

Em ail: jumriani@ulm.ac.id

3 Un iv ersitas Lambung Ma ngkurat, Banjarmasin, In donesia

Em ail: rezky.handy@ulm.ac.id

4 Un iv ersitas Lambung Mangkurat, Ba njarmasin, Indonesia

Em ail: syahar@ulm.ac.id

5 Un iv ersitas Lambung Ma ngkurat, Banjarmasin, In donesia

Em ail: 1910128220034@m hs.ulm.ac.id
} 
data dilakukan melalui triangulasi sumber, waktu, dan teknik. Hasil kajian memastikan bahwa wisata religi di bantaran sungai tepatnya di Kubah Habib Basirih dapat dimanfaatkan untuk mengaktualisasikan sikap religius siswa. Oleh karena itu, guru dapat memanfaatkan dengan merencanakan, melaksanakan, dan mengevaluasi dengan konteks mata pelajaran IPS yang sesuai dengan muatan karakter religius melalui wisata religi di bantaran sungai tepatnya di Kubah Basirih.

\section{INTRODUCTION}

Moral degradation occurs in the behaviour of today's young generation. This is characterized by deviant behaviour such as bullying, brawls, and consuming narcotics. Based on World Drugs Reports 2018 data published by the United Nations Office on Drugs and Crime (UNODC), 275 million people in the world, or 5.6\% of the world's population (aged 15-64 years), have experienced consuming drugs. Meanwhile, in Indonesia, BNN, as the agency responsible for the Prevention and Eradication of Drug Abuse and Illicit Trafficking, recorded the number of narcotics abuse in 2017 as many as 3,376,115 people in the age range of 10-59years. Meanwhile, the number of drug abuse among students in 2018 (from 13 provincial capitals in Indonesia) reached 2.29 million people. Community groups prone to drug abuse are those aged 15-35 years or the millennial generation (Kim et al., 2019). This harms the future of themselves and the family environment, society, and even the country.

The existence of schools as educational institutions needs to be optimized to prevent or prevent complete the issue. Schools are educational institutions where the teaching and learning process fosters student activities (Mutiani et al., 2020). In schools, there is an interaction between students and teachers, interactions between fellow students, interactions between students and the principal, or vice versa. Therefore, every school must have compiled various rules or visions and missions to improve the quality of schools and the quality of graduates not only in the cognitive aspect but also in skills and attitudes (Ramadhanti et al., 2020).

From a social perspective, including religious activities learning in schools is a potential thing to familiarize students with religious activities to be a filter for the emergence of behaviours that reflect moral degradation. As written in the Constitution No. 20 of 2003 concerning the National Education System that education is a conscious and planned effort to create a learning atmosphere and learning process so that students actively develop their potential to have religious-spiritual strength, selfcontrol, personality, intelligence, noble character, and the skills needed for themselves, society, nation, and state (Romanelli et al., 2021).

The education system is expected to prioritize the cognitive aspects and the affective and psychomotor aspects of students. For this reason, schools should carry out learning management that can strengthen students' intelligence in religious behaviour. Furthermore, as written by (Khusminatun \& Makhful, 2021), schools as education providers have the responsibility to educate students to become human beings who are faithful and devoted and able to develop their knowledge.

The utilization of religious activities in the surrounding environment can be done to integrate learning activities with local content. In Banjarmasin, South Kalimantan, religious activities can be found in the Dome of Habib Hamid Bin Abbas Al-Bahasyim. The dome is located at JL Keramat Rt 1, Basirih Village, West Banjarmasin District, Banjarmasin City, South Kalimantan. This dome is a tomb of a cleric, and now it has become part of religious tourism on the Riverbanks of Banjarmasin City, South Kalimantan. As stated by (Winarti et al., 2020) that religious tourism is an activity carried out by a person or group of people to make pilgrimages or visit sites related to the spread of religion, such as mosques, Temple,

Several previous researchers have carried out research related to the integration of religious activities as content in learning to cultivate religious values (Handy et al., 2020) and (Ramadhanti et al., 2020), which focused on batahlil religious activities in mosques. In contrast, this research focuses on religious activities at a place that is part of religious tourism on the river banks in the city of 
Banjarmasin, namely the Habib Hamid Bin Abbas Al-Bahasyim Dome. Therefore, this research aims to explore how to integrate religious tourism in the Habib Hamid Bin Abbas Al-Bahasyim Dome to be used as a learning resource to internalize religious values for students.

\section{METHODS}

This study uses a qualitative approach with a descriptive method. The purpose of the study was to identify the linkage of religious tourism on the riverbanks of Banjarmasin City as a learning resource to actualize religious activities for students. The research was conducted on the river, specifically in the Habib Hamid bin Abbas Bahasyim Dome. The dome is located at JL Keramat Rt 1, Basirih Village, West Banjarmasin District, Banjarmasin City, South Kalimantan.

Researchers conducted interviews, observations, and documentation as data collection techniques to produce data relevant to the research objectives (Bungin, 2015; Sugiyono, 2010). Research informants consisted of several parties, namely visitors, religious tourism managers at the Habib Hamid bin Abbas Bahasyim Dome. In addition, secondary data were obtained from several literature studies, and information relevant to the research, namely literature related to religious tourism and learning resources obtained from the scientific journal literature studies as well as data related to tourism on the riverbanks of Banjarmasin City is obtained from online data from the Banjarmasin City Tourism Office.

The data analysis technique carried out follows the pattern of Miles and Huberman, which begins with data reduction, data presentation, then verification (Lexy J. Moleong \& Tjun Surjaman, 2010; Moleong, 2007). Data analysis is carried out by first sorting the relevant data with the formulation and research objectives, and then the data is presented narratively. Finally, the compiled data is analyzed to get a research conclusion to answer the research problem formulation. During the data analysis, the researcher continued to test the validity of the data using extended observations and triangulation of sources, techniques, and time to test the validity of data.

\section{FINDINGS AND DISCUSSION}

Human life in society is never separated from values and norms. Every human behaviour must be and regulated by the demands of values and norms. Religious values reflect a noble attitude that must be adhered to by individuals and groups of people who are closely related to the relationship between humans and His God both for their own lives and in society (Darda, 2016).

Religious values are closely related to the religious context, which is an individual's inner experience of the awareness of God through his creations. This awareness will manifest in good behaviour and the context of worship because behaviour is a logical consequence of belief. Human behaviour that reflects religious values is based on individual awareness of the existence of the creator. Therefore, it can be reflected by how they behave (Jamaluddin et al., 2020).

Various ways can be done to instil religious values. One of them is through religious tourism. Religious tourism refers to travel to religious sites and destinations motivated by religion and other factors (Jumriani, Mutiani, et al., 2021). Religious tourism can be a tourist trip to reflect religious values because religious tourism increases religious belief, religious knowledge, religious feeling, and religious effect. Increasing attitudes and behaviours that reflect religious values are not just by coming to visit the place. However, it is accompanied by various activities during religious tourism (Romanelli et al., 2021).

The dome of Habib Hamid bin Abbas Bahasyim is a religious tourism object in the city of Banjarmasin, South Kalimantan. Habib Hamid bin Abbas Bahasyim or better known as Habib Basirih is a Banjar cleric. The genealogy, Habib Hamid bin Abbas bin Abdullah bin Husin bin Awad bin Umar bin Ahmad bin Sheikh bin Ahmad bin Abdullah bin Aqil bin Alwi bin Muhammad bin Hasyim bin Abdullah bin Ahmad bin Alwi bin Ahmad Al Faqih bin Abdurrahman bin Alwi Umul Faqih bin Muhammad Shahib Mirbath. 


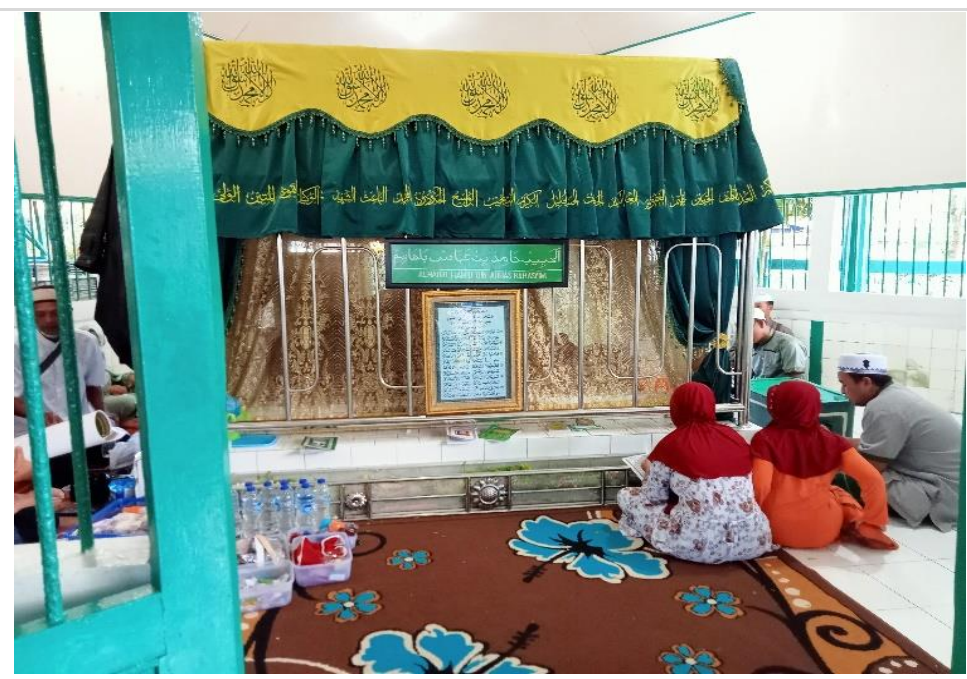

Figure 1. Dome of Habib Hamid bin Abbas Bahasyim

Source: Researcher documentation, o3 July 2021

Dome Habib Hamid bin Abbas Bahasyim is located at Jl Keramat RT 13, Kelurahan Basirih, Banjarmasin City. The dome has become a religious tourism object in the city of Banjarmasin. Its location is on the banks of the river, so the dome is part of religious tourism on the banks of the river. This dome is not only accessible via land transportation but also accessible via river transportation. Therefore, the Habib Basirih dome is part of tourism along the riverbanks of Banjarmasin City.

\section{Religious Activities at the Dome of Habib Hamid bin Abbas Al-Bahasyim}

The dome of Habib Hamid bin Abbas Bahasyim, a religious tour, provides sites that tourists can visit. However, in the dome, various religious activities can be followed and witnessed. The religious activities are the taklim assembly and the basirih festival-first, the Taklim Council. The taklim assembly at the Habib Basirih Dome is held twice a week. Precisely on Thursday and Sunday. This taklim assembly was held around the dome of Habib Hamid bin Abbas Al-Bahasyim by gentlemen who were in RT 09 at the Habib Hamid mosque, which was approximately 50 meters from the Basirih dome. The taklim assembly is held twice a week. Exactly Thursday night and Sunday night. This taklim assembly activity is usually attended by 50 people from the various community in Basirih village. The assembly contents were lectures and tausiyah from Habib or ustadz by discussing the science of jurisprudence and monotheism. However, if the one who gave the tausiyah were Zurich Habib Hamid bin Abbas Al-Bahasyim, namely Habib Faturachman bin Idrus bin Hasan bin Bahasyim, the content of the tausyiah would tell the Habib's karomah and guardianship. However, lectures on the guardianship and kharamah of Habib Hamid were not held every time the assembly was held. Because if you bring in ustadz from outside, then the content of the lectures and tausiyah is more to invite you to remain obedient to Allah.

Second, the Basirih festival. The Basirih festival can be called a recreational da'wah activity attended by the Basirih community and outside Basirih. This recreational da'wah begins with a pilgrimage to the Dome of Habib Hamid bin Abbas Al-Bahasyim and then continues by listening to the story and biography of Habib Basirih. After that, the participants of the basirih festival continued down the Barito river using kelotok to go to the tombs and domes of the scholars. 


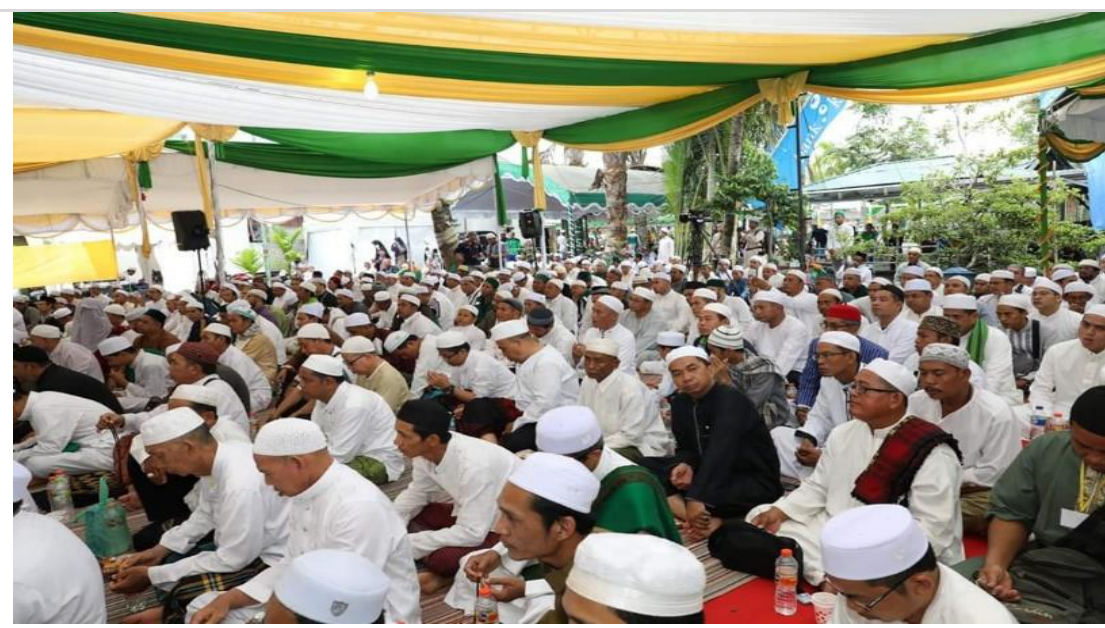

Figure 2. Basirih Festival Visitors

Source, Secondary Data, 2019

When they arrived at the tomb or dome, the participants were invited to listen to the stories and biographies of Sultan Suriansyah and Surgi Mufti Sheikh Jamaluddin on the Miai River. In this series of recreational $d a^{\prime} w a h$, there are also booths where participants can taste the free food available every year, namely 'lakatan' or sticky rice. Not only food, but there are also many stalls selling items such as Koko clothes, skullcaps, and perfume. As stated by the initiator of the Basirih festival, Habib Faturahman bin Idrus bin Husen bin Hamid Bahasyim.

"This basirih festival has been held since 2018. The main purpose of this activity is da'wah. I call this da'wah method recreational da'wah. So besides being able to broadcast goodness, we also follow the instructions from the mayor of Banjarmasin, to turn on and activate the riverside tourism which is the hallmark of the capital city of South Kalimantan."

\section{Dome of Basirih Religious Tourism and Its Relation as Social Studies Learning Resources}

Education in schools is directed not only to build the knowledge of future generations but also to build a variety of characters. One of them is the religious character, which impacts individual attitudes and positively contributes to religious life in the community. This is undoubtedly a preventive effort to prevent various immoral behaviours by future generations (Handy et al., 2020; Jumriani, Mutiani, et al., 2021; Mutiani et al., 2021). On that basis, integrating religious activities through learning will make a positive contribution to students.

Religious activities are all actions, deeds, or words that someone carries out. In contrast, those actions or actions and words are related to religion, all of which are carried out because of belief in God with teachings and obligations related to belief (Jumriani, Mutiani, et al., 2021; Jumriani, Syaharuddin, et al., 2021). This is in line with the opinion that religious behaviour is behaviour based on awareness of the existence of God Almighty.

Integrating religious activities in the environment of students into learning can be done through religious tourism. Religious tourism is travel to religious sites and destinations, motivated by religion and other factors. For example, in the city of Banjarmasin, religious tourism can be done by doing a river tour to the dome of the basilica. By doing religious tourism, many religious activities can be carried out by participants so that they can learn and travel (Mahfuzah et al., 2020; Rusmaniah et al., 2021).

Social studies subjects are suitable subjects to integrate religious tourism trips on the river banks as a learning resource for students. Social studies are learning aims to shape the characteristics of students who have various characters to live in society. One of them is religious character. Therefore, doing religious tourism in the Basirih Dome can be a part that social studies learning does not only aim to understand a social phenomenon in the context of learning, but students are also able 
to determine attitudes in various moral degradations that occur in society (Aslamiah et al., 2021; Subiyakto et al., 2020).

The integration of religious activities through religious tourism on the riverbanks of the city of Banjarmasin as social studies learning resource will give strength to the affective, psychomotor, and cognitive domains. Strictly speaking, when this is implemented in social studies learning in schools, it will provide holistic student learning outcomes in all areas of learning. It will give a different colour from what has happened so far, where the cognitive domain is so dominant or even the only one developed in social studies learning at school.

\section{CONCLUSION}

The actualization of religious behaviour to students can be done in the school environment and can be done by utilizing religious tourism objects in the surrounding environment. By travelling on religion as a learning resource, students can learn from sources focused on textbooks. Therefore, integrating it with related subjects is a solution to actualize the religious behaviour of students, to prevent and even overcome the moral degradation of the current generation. Social study is a subject that fits the context, as social science has a strong relationship with the context of the society in the religious aspect. The goal of social studies learning is to foster students to live in a community environment, one of which should carry out religious values. When this is done, it is hoped that student learning outcomes will be mastery of a collection of knowledge in the form of facts, concepts, or principles and embedded attitudes and skills in the context of religious aspects needed in social life.

\section{REFERENCES}

Aslamiah, A., Abbas, E. W., \& Mutiani, M. (2021). 21st-Century Skills and Social Studies Education. The Innovation of Social Studies Journal, 2(2), 82-92.

Bungin, B. (2015). Metodologi penelitian kualitatif : Aktualisasi Metodologis Kearah Ragam Varian Kontemporer(Ed.1, Cet.). Rajawali Pers.

Darda, A. (2016). Integrasi Ilmu dan Agama: Perkembangan Konseptual di Indonesia. At-Ta'dib, 1O(1). https://doi.org/10.21111/at-tadib.v10i1.323

Handy, M. R. N., Mutiani, M., Putra, M. A. H., \& Jumriani, J. (2020). The Religious Values in Tradition of Batahlil in Banjar Pahuluan Community. The Kalimantan Social Studies Journal, 2(1), 39-47.

Jamaluddin, J., Syaharuddin, S., \& Putra, M. A. H. (2020). The Form of Basirih Society Social Interaction in The Dome of Habib Hamid Bin Abbas Al-Bahasyim as a Learning Resource on Social Studies. The Kalimantan Social Studies Journal, 1(2), 159-168. https://doi.org/10.20527/KSS.V1I2.2038

Jumriani, J., Mutiani, M., Putra, M. A. H., Syaharuddin, S., \& Abbas, E. W. (2021). The Urgency of Local Wisdom Content in Social Studies Learning: Literature Review. The Innovation of Social Studies Journal, 2(2), 103-109.

Jumriani, J., Syaharuddin, S., Hadi, N. T. F. W., Mutiani, M., \& Abbas, E. W. (2021). Telaah Literatur ; Komponen Kurikulum IPS Di Sekolah Dasar pada Kurikulum 2013. Jurnal Basicedu, 5(4), 2027-2035. https://doi.org/10.31004/BASICEDU.V5I4.1111

Khusminatun, K., \& Makhful, M. (2021). Kultur Sekolah dalam Peningkatan Perilaku Keagamaan Siswa di Sekolah Menengah Kejuruan Negeri 2 Purwokerto. Alhamra: Jurnal Studi Islam, 1(2), 118-127.

Kim, B., Kim, S. (Sam), \& King, B. (2019). Religious tourism studies: evolution, progress, and future prospects. Https://Doi.Org/10.1080/O2508281.2019.1664084, 45(2), $185-203$. https://doi.org/10.1080/02508281.2019.1664084

Lexy J. Moleong, \& Tjun Surjaman. (2010). Metodologipenelitian kualitatif. PT. Remaja Rosdakarya. Mahfuzah, M., Subiyakto, B., \& Putra, M. A. H. (2020). The Form of Religious Community Activities at Kelayan B as a Learning Resources on Social Studies. The Innovation of Social Studies 
Journal, 1(2), 150-157.https://doi.org/10.20527/iis.v1i2.2092

Moleong, L. J. (2007). Metodologi Penelitian Kualitatif Edisi Revisi (Revisi, Vol. 103). PT. Remaja Rosdakarya.

Mutiani, M., Noortyani, R., Tetep, T., Jumriani, J., \& Widyanti, T. (2020). Strengthening Islamic Environmental Awareness through Exploring Poetry as a Learning Resource in Social Studies. Islam Realitas: Journal of Islamic and Social Studies, 6(2), 150-163. https://doi.org/10.30983/islam_realitas.v6i2.3387

Mutiani, M., Sapriya, S., Handy, M. R. N., Abbas, E. W., \& Jumriani, J. (2021). Pembinaan Etika Peserta Didik Melalui Pembelajaran Tematik-Integratif Di Sekolah Dasar. EDUKATIF : JURNAL ILMU PENDIDIKAN, 3(3), 704-709. https://doi.org/10.31004/edukatif.v3i3.397

Ramadhanti, W., Abbas, E. W., \& Jumriani, J. (2020). Religious Activities in The Great Mosque Al Munawwarah Banjarbaru. The Kalimantan Social Studies Journal, 2(1), 69-75. https://doi.org/10.20527/KSS.V2I1.2466

Romanelli, M., Gazzola, P., Grechi, D., \& Pollice, F. (2021). Towards a sustainability-oriented religious tourism. Systems Research and Behavioral Science, 38(3), 386-396.

Rusmaniah, R., Mardiani, F., Handy, M. R. N., Putra, M. A. H., \& Jumriani, J. (2021). Social Services Based on Institutional for Youth Discontinued School. The Innovation of Social Studies Journal, 2(2), 151-158. https://doi.org/10.20527/IIS.V2I2.3082

Subiyakto, B., Widyanti, R., Basuki, \& Syaharuddin. (2020). Revitalizing public university innovativeness through learning organization. Polish Journal of Management Studies, Vol. 21, $N$. https://doi.org/10.17512/pjms.2020.21.1.27

Sugiyono, S. (2010). Metode Penelitian Kuantitatif dan Kualitatif dan R\&D. ALFABETA Bandung. https://www.pdfdrive.com/prof-dr-sugiyono-metode-penelitian-kuantitatif-kualitatif-dan-rdintro-e56379944.html

Winarti, A., Murtana, A., \& Daulay, S. (2020). The Mosque Colo as Alternative Tourism Destination in Kudus. 76-78. https://doi.org/10.2991/AHSR.K.200723.018 